\title{
Phomopsis sp. CAUSANDO PODRIDÃO EM FRUTOS DE BACURIZEIRO
}

\author{
DINALDO R. TRINDADE, LUIZ S. POLTRONIERI, FERNANDO C. ALBUQUERQUE, \\ M. LOURDES R. DUARTE \& J. EDMAR U. CARVALHO
}

Embrapa Amazônia Oriental, Cx .Postal 48, CEP 66095-100, Belém, PA, e-mail: dinaldo@cpatu.embrapa.br

(Aceito para publicação em 18/04/2002)

Autor para correspondência: Dinaldo Rodrigues Trindade

\section{ABSTRACT \\ Phomopsis sp. causing fruits rot in bacurizeiro}

A fruit rot detected in "bacurizeiro" (Platonia insignis) was demonstrated to be caused by Phomopsis sp.

O bacurizeiro (Platonia insignis Mart.) é uma fruteira típica da região litorânea do estado do Pará, explorada de maneira extrativista, mas em fase de domesticação. Os frutos dessa espécie, pelo sabor e aroma peculiar, são bastante utilizados no preparo de refrescos, sorvetes, cremes, doces, compotas ou mesmo consumidos in natura, pela população da Amazônia e dos estados do Maranhão e Piauí, onde é também encontrado espontaneamente (Carvalho et al. Embrapa Amazônia Oriental. Comunicado Técnico no 11 , 1999). Embora mais conhecido como planta frutífera, apresenta madeira com boas características tecnológicas e multiplicidade de usos (Mainieri \& Chimelo. Fichas de características de madeiras brasileiras. 2. Ed. São Paulo: IPT, 1989). Em algumas áreas de dispersão do bacurizeiro, os frutos, na fase de maturação, têm apresentado lesões necróticas que atingem até $50 \%$ do fruto. As lesões inicialmente externas avançam para o interior do fruto tornando-o impróprio para o consumo (Figura 1-A). A partir de amostras de frutos lesionados foram feitos isolamentos em meio de cultura BDA, tendo-se isolado um fungo com características do gênero Phomopsis. Efetuou-se o teste de patogenicidade inoculandose o fungo em frutos sadios de bacurizeiro, obtendo-se a reprodução dos sintomas semelhantes aos que ocorrem no campo com posterior reisolamento. Observou-se a formação de picnídios escuros, com ostíolo em forma de pera, conidióforos simples, conídios hialinos com gotas nas extremidades, predominantemente elipsóides, sem septos, unicelulares de forma ovóide (alfa conídio) medindo 3,0 7,2 x 1,56 - 2,52 $\mu \mathrm{m}$ e hialinos, sem gotas, filiformes, a maioria curvos em uma das extremidades, sem septos (beta conídio) medindo 8,4 - 33,6 x 1,2 - 1,56 $\mu \mathrm{m}$ (Figura 1-B), característicos do fungo Phomopsis sp. (Barnett \& Hunter, APS PRESS, 1988). Portanto, confirma-se assim que o agente causal da podridão dos frutos do bacurizeiro é um fungo do gênero Phomopsis. Este é o primeiro relato desse fungo infetando naturalmente frutos de bacurizeiro no Brasil.

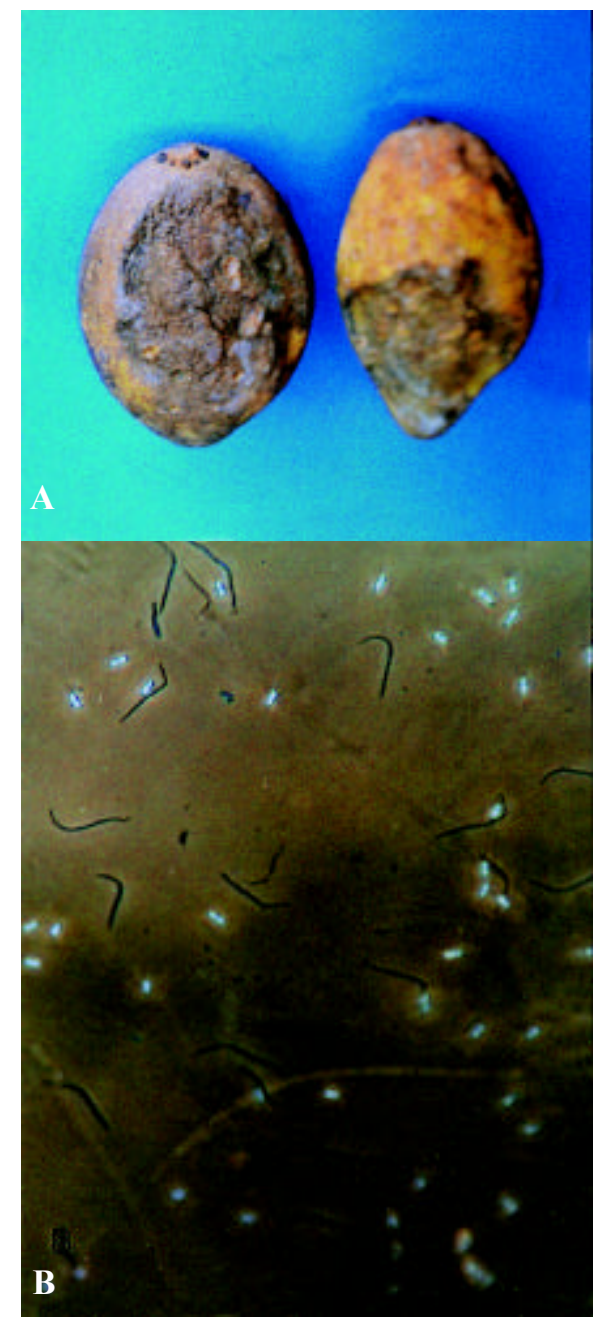

FIG. 1 - A- Lesão necrótica causada por Phomopsis sp em frutos de bacurizeiro (Platonia insignis); Bconídios alfa e beta de Phomopsis sp. isolado de frutos de bacurizeiro. 